球状黒鉛鋳鉄の疲労強度に及ぼす黒鉛の

形状，寸法，分布の影響十

\author{
遠 藤 正 浩* \\ Effects of Graphite Shape, Size and Distribution on the \\ Fatigue Strength of Spheroidal Graphite Cast Irons
}

by

\title{
Masahiro ENDO*
}

\begin{abstract}
Spheroidal graphite (SG) cast iron is a typical porous material which contains numerous small defects (graphites) in the matrix.

In order to clarify the geometrical parameter for the quantitative evaluation of the effect of surface graphite on the fatigue strength of SG cast iron, rotating bending fatigue tests were carried out on the plain- and notched-specimens of as-cast FCD60 and FCD70.

It is concluded from the microscopic observation that the fatigue limit is controlled by the maximum size of surface graphite defined by the square root of the projected area of graphite $\left(\sqrt{a r e a}_{\max }^{*}\right)$. The value of $\sqrt{a r e a}_{\max }^{*}$ in a definite surface area of the specimen can be predicted by the statistics of extreme values. The predicted values of $\sqrt{a r e a}_{\max }^{*}$ approximately agree with the critical size of artificial notch which does not act to reduce the fatigue strength. The value $\sqrt{a r e a}_{\max }^{*}$ is in general considered to be the controlling geometrical parameter for the prediction of fatigue strength of porous materials.
\end{abstract}

Key words : Fatigue strength, Small cracks, Small defects, Porous materials, Spheroidal graphite cast irons, Geometrical parameter, Maximum size of defects

\section{1 緒言}

球状黒鉛鋳鉄平滑材の疲労強度に関しては，黒鉛の 形状と寸法や基地組織の影響についてすでに多くの研 究がある. 特に, 祖父江注平均黑鉛直径と停留き裂の 寸法（または基地組織の硬さ）を用いた簡便な疲労強 度の予測式を提案し，基地組織と黒鉛寸法を変えた多 くの材質でその有効性を示している.

一方, 著者ら 注種々の微小久陥や微小き裂をもつ 金属材料の疲労強度の予測式として次式を提案した。

$$
\sigma_{w}=1.43\left(H_{v}+120\right) /(\sqrt{\text { area }})^{1 / 6}
$$

ここで, $\sigma_{w}$ : 疲労限度 $\mathrm{MPa}, H_{v}$ : ビッカース硬さ $\left(\mathrm{kgf} / \mathrm{mm}^{2}\right), \sqrt{a r e a}$ : 欠陥やき裂を最大引張応力方 向に垂直な面に投影した投影面積の平方根 $\mu \mathrm{m}$ である. 寸法が既知である種々の微小欠陥や微小き裂をもつ 20 種類以上の材料について，この式による予測值と 実験値を比較したところ, 式の予測誤差は $10 \%$ 以内 であることが確かめられた。年の後も, 介在物をもつ 高強度鋼の疲労強度評価卢腐食ピットを有する鋼板の 疲労強度予測などに用いられよい成績をあげている。

本研究は, 多孔金属材料の疲労強度予測への式(1)の 適用の可能性を探るため, 試験材料に球状黒鉛鋳鉄を
選び, 欠陥（黒鉛部）の形状, 寸法, 分布の影響につ いて検討を行い, 式(1)中の $\sqrt{a r e a}$ の見積り方を明ら かにすることを目的としている.

球状黑鉛鋳鉄の場合，欠陥内部に黒鉛が詰まってい るが, この黒鉛が疲労強度に無視できない程度の影響

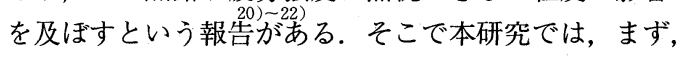
疲労強度を決定していると考えられる試験片表面の欠 陥に注目して，欠陥内部の黒鉛の影響と欠陥相互の干 渉の影響について検討を行い, その後, 多様な形状, 寸法, 分布をもつ黒鉛の情報を統一する欠陥の幾何学 的パラメー夕について検討する.

\section{2 使用材料，試験片形状および実験方法}

実験に供した球状黒鉛鋳鉄は，FCD60，FCD70 相 当材である. それぞれ同一溶湯より JIS G5502 Y 型 $\mathrm{B}$ 号ブロックの形状に鋳造した後, 各ブロック底部 より一本ずつ素材を採取し，鋳放しのまま使用した。

Table I に化学成分と機械的性質を示す．試験片は機 械加工により Fig. 1 (a)の形状に製作した. 危険表面積 をそろえるために試験部を若干細くした．Fig. 2 に横 断面の組織写真を示す. FCD60 と FCD70 の黒鉛球 状化率は, ともに $84 \%$ であり，パーライト面積率は

$\dagger$ 原稿受理 昭和63年12月26日 Received Dec. 26,1988

* 正会員 福岡大学工学部 福岡市城南区七隈, Faculty of Engineering, Fukuoka University, Nanakuma, Jonan-ku, Fukuoka 
Table I. Chemical composition and mechanical properties. Chemical composition, \%

\begin{tabular}{|c|c|c|c|c|c|c|c|}
\hline & $\mathrm{C}$ & $\mathrm{Si}$ & $\mathrm{Mn}$ & $\mathrm{P}$ & s & $\mathrm{Cu}$ & $\mathrm{Mg}$ \\
\hline FCD60 & 3.76 & 2.98 & 0.41 & 0.023 & 0.015 & 0.30 & 0.052 \\
\hline FCD70 & 3.77 & 2.99 & 0.44 & 0.023 & 0.011 & 0.47 & 0.058 \\
\hline & \multicolumn{7}{|c|}{ Mechanical properties } \\
\hline & & & & \multicolumn{2}{|c|}{ FCD 60} & \multicolumn{2}{|c|}{ FCD70 } \\
\hline & \multicolumn{3}{|c|}{ UTS, MPa } & \multicolumn{2}{|r|}{641} & \multicolumn{2}{|l|}{734} \\
\hline & \multicolumn{3}{|c|}{ Elongation, \% } & \multicolumn{2}{|r|}{14.1} & \multicolumn{2}{|l|}{8.0} \\
\hline & \multicolumn{3}{|c|}{ Vickers hardness (10kg) } & \multicolumn{2}{|r|}{216} & 241 & \\
\hline
\end{tabular}

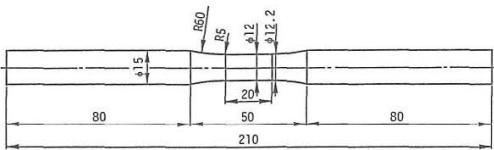

(a) Unnotched specimen

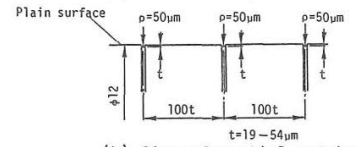

(b) Circumferential notches

Fig. 1. Dimensions of specimen and notch.

それぞれ $47 \%$ ，72％である. Fig. 2 の試料表面に顔 を出している各黒鉛の占める面積と真円度の測定は, 100 倍の光学顕微鏡下で自動画像解析装置 PIAS LA500を用いて直接行った。

Fig. 1 (a)の試験片は試験前までに Fig. 3 に示す表面 処理を行い, 2 種類の平滑材と切欠き材を製作した. 平滑材は, Fig. 4 に示すように, 表面層が〜 $2 \mu \mathrm{m}$ 除 去される程度のわずかな電解研磨を行うことによって, 試験片表面の欠陥内の黒鉛のみを取り除いた ep 材と, 行わずに欠宿内に黒鉛が詰まっている N-ep 材を準 備した. Fig. 5 に電解研磨によって黒鉛が除去される 過程を示す. 上段の写真は欠陥縁の基地に焦点を合わ せたもので，下段は穴の底に合わせたものである. 表 面の穴の形状はほとんど変化せず深さだけが変化する. 黒鉛がほほ除去され穴の底に明るいフェライト組織が 現れた後は深さもほとんど変化しなくなる。このよう

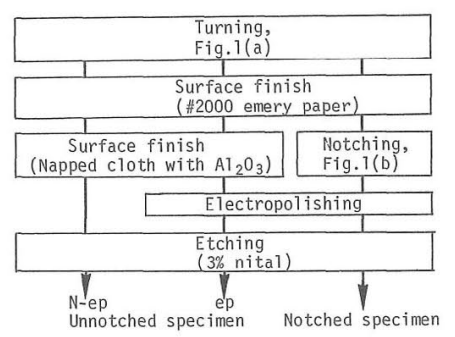

Fig. 3. Surface treatment of specimens.

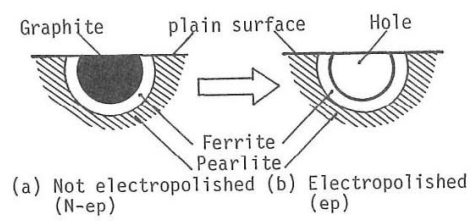

Fig. 4. Schematic of surface defect.

に，わずかの電解研磨によって，穴の形状はそのまま に黒鉛だけを取り除くことができる。電解研磨液はり ん酸 $2000 \mathrm{cc}$ ，ゼラチン $66 \mathrm{~g}$ ，しゅう酸 $66 \mathrm{~g}$ である. 切欠き材は，Fig.1(b)に示すように，一本の試験片表 面にほぼ同じ深さの極めて浅い円周切欠きを深さの 100 倍の間隔をおいて 3 条切削加工した後, ep 材と 同じ表面处理を行った。, ひとつの切欠きの深さは浅い ところと深いところで 1 ～13 $\mu \mathrm{m}$ の差があるが，最深 部の深さを切欠き深さ $t$ とした。

使用した試験機は，小野式回転曲げ試験機（容量： $100 \mathrm{Nm}$ ，回転数：3400 rpm）である.

応力は, 試験部中央の外径で定義した公称曲げ応力 である。

疲労限度 $\sigma_{w}$ は $10^{7}$ 回の繰り返しに耐えた最高の公 称応力である. 試験応力の最小きざみ幅は $5 \mathrm{MPa}$ と した.

\section{3 実験結果と考察}

\section{$3 \cdot 1$ 疲労強度に及ぼす黒鉛の影響}

球状黒鉛鋳鉄中の黒鉛の強度は基地組織に比べてか なり低く応力をほとんど負担しないとして，通常その

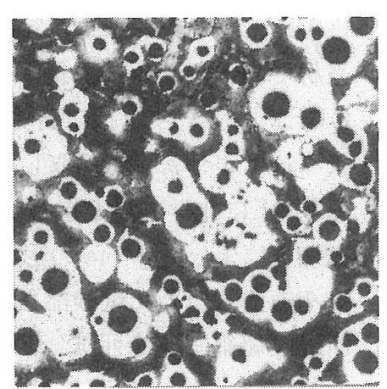

(a) FCD60
$200 \mu \mathrm{m}$

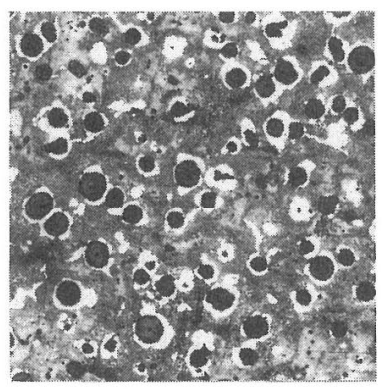

(b) FCD70

Fig. 2. Metallographic structure. 


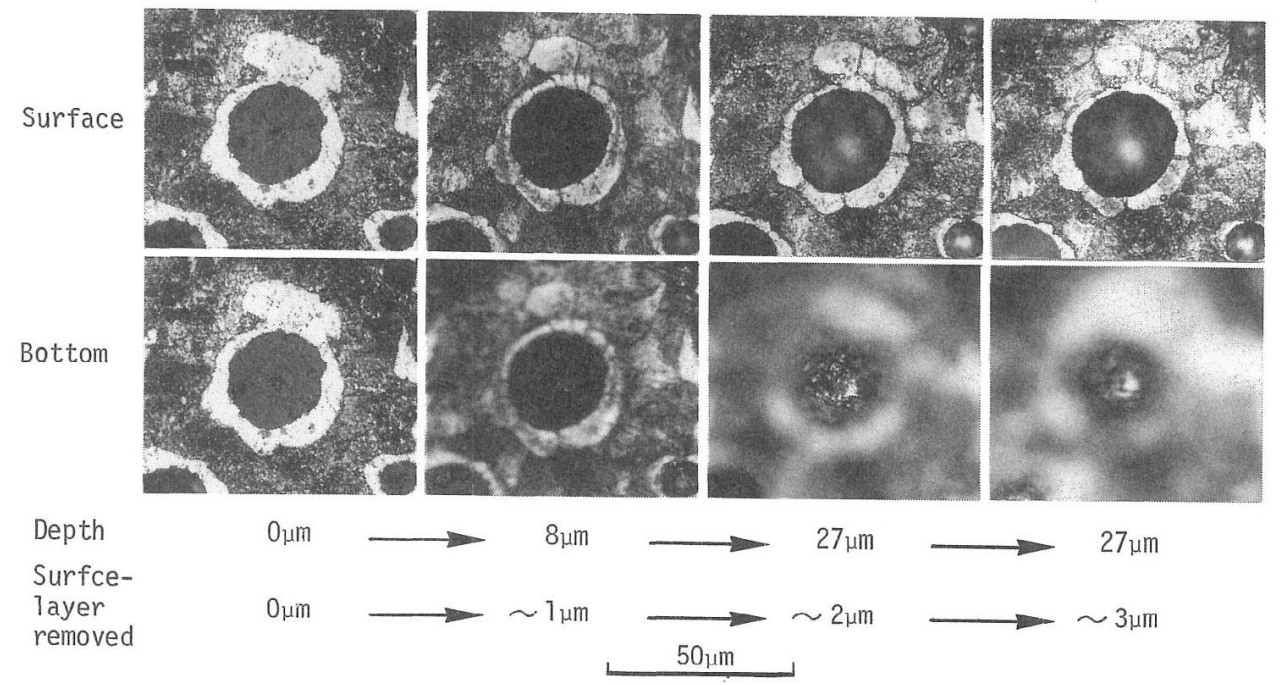

Fig. 5. Change of surface defect due to electropolishing (FCD70).

存在は無視して考えられてきた。 しかし最近，矢野は（21) 黑鉛の弾性効果について検討を行い, 黒鉛の充てん度 が高くなると基地組織が黒鉛を圧縮して疲労強度が 20〜24％高くなることを明らかにして，黑鉛の応力 負担効果が無視できない場合があることを指摘してい る。また, 小川ら゙は,き裂の開閉口の際に黒鉛が粉砕 され，その微分末がき裂面に入り込みき裂閉口を誘起 し，下限界特性に影響を与えるとしている。これらは いずれも黒鉛部を穴とみなせない場合があることを示 すものである。そこで，本研究では表面黒鉛の影響を 調べるために, Fig. 4 に示した N-ep 材と ep 材の 2 種類の平滑材について回転曲げ度労試験を行った.

Fig. 6 に $S-N$ 曲線を示す. FCD60，FCD70 とも に N-ep 材と ep 材の疲労強度にめたっった違いは認め られない。本実験で使用した材料の場合, 疲労強度に 及ほ寸表面の黒鉛の影響は小さく，表面欠陥部は黒鉛
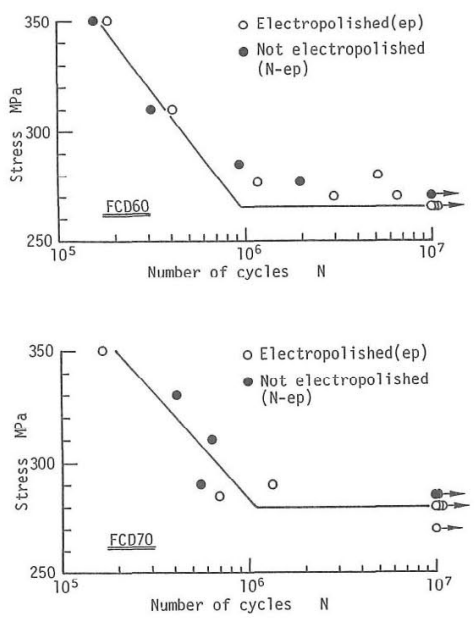

Fig. 6. $S-N$ curve.
の存在を無視して穴と考えてよいようである。

\section{$3 \cdot 2$ 疲労限度における試験片表面の微視的観察}

Fig. 7 は痩労限度で観察された停留き裂である。他 の研究者らう結果と同様に, 再材の疲労限度は, 黑鉛 からき裂が発生する限界応力ではなく，発生したき裂 が伝ぱを停止する限界応力といえる，ただし，停留き 裂は試験片表面に顔を出している全ての黒鉛に観察さ れるわけではなく，むしろ疲労限度の応力でき裂を発 生させる条件が満たされなかったとみられる黒鉛の方 が多い。加藤らのうち密な調查によれば, FCD 60 平滑 材の冹労限度で停留き裂が発生している黒鉛の数は表 面の全黑鉛数の約 $5 \%$ にすぎない。ささらに, 広瀬ら の FCD60 相当材の観察結果と同様に, ひとつの黑鉛 から発生した停留き裂が他の黒鉛のき裂と連結してい ることは極めて少なかった.これらのことは, 疲労限 度に执いては欠陥相互の干渉の影響が小さいことを示 唆するものである.

また, 停留き裂を持つ黒鉛の寸法は, 表面に出現し ている切断面の面積で比較する限り, き裂をもたない 周辺の黒鉛に比べて小さいことが多かった. 力学的に は，同一直径の球状空かであれば，それが表面に接す るように位置しているときに, き裂の発生(応力集 中) の観点からも発生したき裂の停留（応力拡大係 数）の観点からも最も厳しいと考えられる. Fig. 7(c) のように，表面からはほとんどき裂だけが観察される ことがあるが,この場合は表面のすぐ下に黒鉛が存在 していると想像される. 停留き裂をもつ黒鉛の表面下 の三次元形状が Clement ららによって 2 例報告されて いるが,この場合も黒鉛の中心は表面より下である.

$3 \cdot 3$ 疲労強度を評価するための欠陥の幾何学的パ ラメータ $\sqrt{\text { area }}_{\text {max }}^{*}$ 


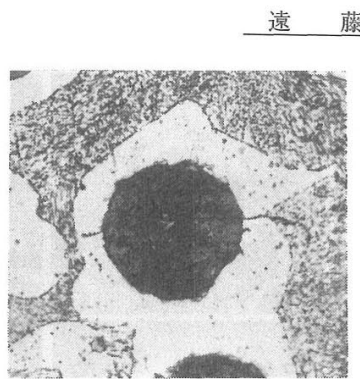

(a) FCD60.(N-ep) $\sigma_{w}=270 \mathrm{MPa}$

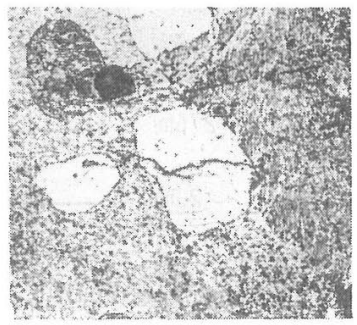

(c) $\operatorname{FCD60}(\mathrm{N}-\mathrm{ep})$ $\sigma_{w}=270 \mathrm{MPa}$ 正浩

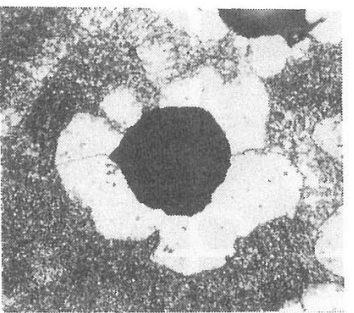

(b) $F \operatorname{CD70}($ ep) $\sigma_{\mathrm{w}}=280 \mathrm{MPa}$

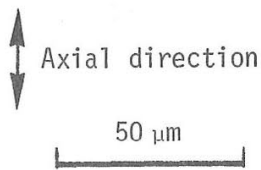

Fig. 7. Nonpropagating microcracks observed on the surface of unnotched specimens.

表面欠陥は黒鉛の存在を無視した穴とみなすことが でき，また，疲労限度は欠陥から発生したき裂の伝ぱ 限界条件によって決まっているから，これまでの著者 らの研究々) 14) 同様に, 久陥の問題を微小き裂の問題とし てとらえることができる。この場合，黒鉛欠宿の形状 と寸法の影響を統一寸る幾何学的パラメータには

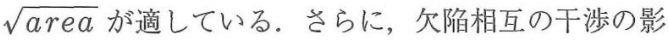
響は小さいようなので，一本の試験片の強度は，最弱 リンク仮説に従って試験片に扔ける最小強度の部分, すなわら最大の $\sqrt{a r e a}$ をもつ黒鉛が存在する部分の 強度によって決まることが予想される（組織の強度の ばらつきが小さいことが前提)。先に述べたように， 破壊力学の観点からは，欠陥は材料の表面（厳密には 表面直下）に位置するとき最も有害である。また， 観察結果も表面近傍に存在する黒鉛が疲労強度決定に 支配的役割を果たしていることを示唆している。し たがって，試験片内の無数の黒鉛の中でも特に危険 表面層内に存在する最大の黑鉛の寸法 $\sqrt{a r e a}$ max

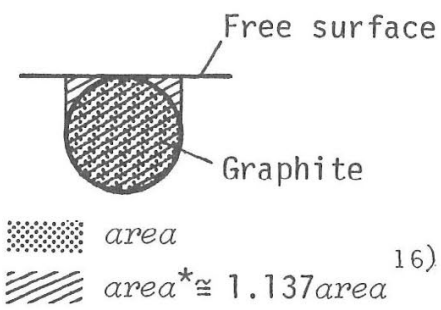

Fig. 8. A graphite just below the surface.
注目しなくてはならない. Fig. 8 に示すように, $\sqrt{\text { area }}_{\text {max }}$ をもつ黒鉛が表面直下に存在する場合は, 表面と欠陥との間の材料はき裂が発生した後には強度 的にほとんど意味がないので，むしろ次式で若千大き く補正した $\sqrt{a r e a}_{\text {max }}^{*}$ の寸法をもつ表面欠陥とする のが合理的である。

$$
\sqrt{\text { area }}_{\max }^{*} \cong 1.066 \sqrt{\text { area }}_{\text {max }}
$$

$\sqrt{\text { area }}_{\text {max }}^{*}$ が球状黑鉛鋳鉄の疲労強度を予測する 際に，式(1)で採用すべき幾何学的パラメータである. 式(2)によって補正する前の $\sqrt{\text { area }}_{\text {max }}$ を $\sqrt{\text { area }}_{\text {max }}^{*}$ のかわりに使用しても誤差はそれほど大きくならない。 現在の非破偯検查に扔ける探傷技術の水準は，ここ で問題としている数 $\mu \mathrm{m}$ から数百 $\mu \mathrm{m}$ の微小な欠陥の 形状，寸法，位置を精度よく測定できるまで達してい ない、そこで、ここでは村上らの年手法にならい極值統 計を用いて次の手順で $\sqrt{a r e a}_{\text {max }}$ の值を見積った。

本実験では，黒鉛の面積 area の測定は，試験片 の横断面をバフ研磨で仕上げした後，100 倍の光学顕 微鏡から直接画像を取り达んで自動画像解析装置によ り行った。一回の測定で対象とした視野の面積は $S_{0}$ $=0.077 \mathrm{~mm}^{2}$ である． $S_{0}$ を基準面積にとり，この中 に存在する黒鉛の面積の最大值の平方根を $\sqrt{\text { area }}_{\text {max }, i}(i=1$ 一測定回数）とする。市る程度の 回数測定すれば, $\sqrt{a r e a}_{\text {max }, i}$ の累積頻度分布は極值 統計に従うことが期待される。

Fig. 9 は FCD60 と FCD70の $\sqrt{\text { area }}_{\max , i}$ の累積 頻度分布を極值確率紙にプロットしたものである。い 

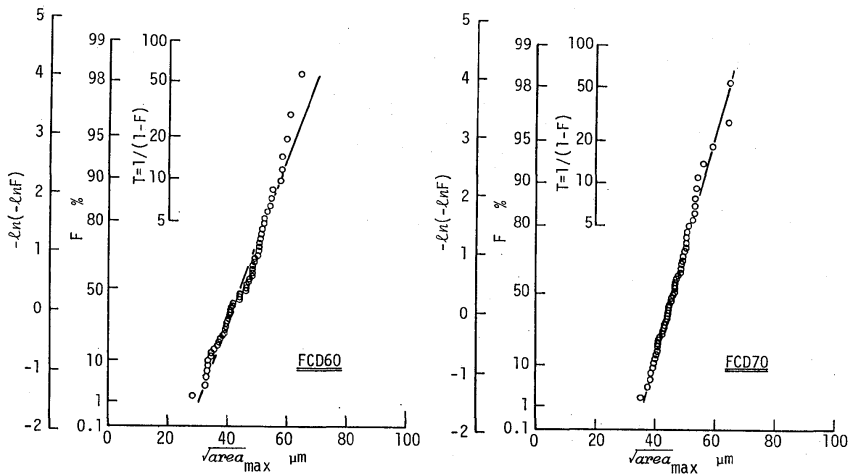

Fig. 9. Distribution of $\sqrt{a r e a}_{\text {max }}$

ずれの分布も直線性がよく, $\sqrt{a r e a}$ の最大值分布が 極值統計に従っていると考えられる. 試験片表面層に 存在する黒鉛の $\sqrt{a r e a}$ の最大值は, Fig. 9 の直線と 再帰期間 $T$ の交点の值として予測できる. 本実験で 使用した平滑材一本当りの危険表面積は $S=754 \mathrm{~mm}^{2}$ である (Fig. 1 (a)参照). 再帰期間は, $N$ 本の試験片 に対して $T=N S / S_{0}$ で与えられる. 最小二乗法で Fig. 9 の直線を求めて, $N=1 \sim 10$ の場合について $\sqrt{\text { area }}_{\text {max }}$ の值を計算すると, FCD60 では 107〜124 $\mu \mathrm{m}$, FCD70では 92〜104 $\mu \mathrm{m}$ と予測される. また, 式(2)より $\sqrt{a r e a}_{\max }^{*}$ の值を計算すると FCD60 では 114〜132 $\mu \mathrm{m}$, FCD70 では 98〜111 $\mu \mathrm{m}$ となる.

$3 \cdot 4$ 疲労強度に害を与えない欠陥の限界寸法と $\sqrt{\boldsymbol{a r e a}}_{\max }^{*}$ の関係

前節で求めた $\sqrt{a r e a}_{\text {max }}$ の值が試験片の危険表面 層に存在する黒鉛の $\sqrt{a r e a}$ の最大值と予想されるが,

Table II. Experimental results of notched specimens.

\begin{tabular}{|c|c|c|c|c|}
\hline $\begin{array}{l}\text { Material } \\
\text { (Stress) }\end{array}$ & $t \mu \mathrm{m}$ & $\sqrt{\text { area }} \mu \mathrm{m}$ & \begin{tabular}{|l|l}
$\times$ Broken \\
$\bigcirc$ Not broken
\end{tabular} & $\begin{array}{l}\text { Number of } \\
\text { cycles }\end{array}$ \\
\hline \multirow{3}{*}{$\begin{array}{c}\text { FCD60 } \\
(265 \mathrm{MPa})\end{array}$} & $\begin{array}{l}19 \\
24 \\
21\end{array}$ & $\begin{array}{l}60 \\
76 \\
66\end{array}$ & $\begin{array}{l}0 \\
0 \\
0\end{array}$ & 10000000 \\
\hline & $\begin{array}{l}30 \\
27 \\
30\end{array}$ & $\begin{array}{l}95 \\
85 \\
95\end{array}$ & $\begin{array}{l}0 \\
\times \\
0\end{array}$ & 983000 \\
\hline & $\begin{array}{l}38 \\
46 \\
38\end{array}$ & $\begin{array}{l}120 \\
145 \\
120\end{array}$ & $\begin{array}{l}0 \\
0 \\
\times\end{array}$ & 708400 \\
\hline \multirow{3}{*}{$\begin{array}{l}\text { FCD70 } \\
(280 \mathrm{MPa})\end{array}$} & $\begin{array}{l}33 \\
33 \\
32\end{array}$ & $\begin{array}{l}104 \\
104 \\
101\end{array}$ & $\begin{array}{l}0 \\
0 \\
0\end{array}$ & 10000000 \\
\hline & $\begin{array}{l}42 \\
42 \\
40\end{array}$ & $\begin{array}{l}133 \\
133 \\
126\end{array}$ & $\begin{array}{l}0 \\
\times \\
0\end{array}$ & 960000 \\
\hline & $\begin{array}{l}54 \\
50 \\
54\end{array}$ & $\begin{array}{l}171 \\
158 \\
171\end{array}$ & $\begin{array}{l}0 \\
\times \\
0\end{array}$ & 268500 \\
\hline
\end{tabular}

Table III. Comparison of $\sqrt{a r e a}_{\max }^{*}$ with $\sqrt{a r e a}_{0}$.

\begin{tabular}{c|c|c}
\hline Material & $\sqrt{\text { area }}_{\max }^{*}(N=1 \sim 10)$ & $\sqrt{\text { area }}$ \\
\hline FCD60 & $114 \sim 132 \mu \mathrm{m}$ & $76 \sim 84 \mu \mathrm{m}$ \\
\hline FCD70 & $98 \sim 111 \mu \mathrm{m}$ & $104 \sim 132 \mu \mathrm{m}$ \\
\hline
\end{tabular}

実際に試験片の黒鉛の中から $\sqrt{a r e a}_{\text {max }}$ の值をもつ 黒鉛を探しだし，さらにその黒鉛が試験片の疲労強度 を決定していることを確認するのは極めて困難である. しかし，もし $\sqrt{a r e a}_{\text {max }}$ 程度の寸法をもつ黒鉛が表 面近傍に存在して疲労限度を決定しているとすれば, 試験片表面に $\sqrt{a r e a}_{\max }^{*}$ と同程度の $\sqrt{a r e a}$ をもつ 欠陥を人工的につけたとしても疲労強度は大きく低下 しないと予想される。 そこで，切欠き半径を $\rho=50$ $\mu \mathrm{m}$ と一定にして切欠き深さを $t=19 \sim 54 \mu \mathrm{m}$ と変化 させた円周切欠きをもつ試験片を準備して, 平滑材 (ep 材) の疲労限度の応力のもとで回転曲げ疲労試 験を行い, 疲労強度に影響を及ぼさない切欠きの $\sqrt{a r e a}$ の限界值 $\sqrt{a r e a}$ 皇調べてみた。切欠きの $\sqrt{a r e a}$ の值は次式で計算される.

$$
\sqrt{\text { area }}=\sqrt{10} t \cong 3.16 t
$$

実験結果を Table II に示す. 一本の試験片は 3 条 の切欠きをもっている. Table II で， X印が試験片を 破断に導いた切欠きであり，○印は破断に至らなかっ た切欠きである. $\sqrt{\text { area }}_{0}$ の值は, $76 \sim 84 \mu \mathrm{m}$ (FCD60)，104〜132 $\mu \mathrm{m}$ (FCD70）の範囲内にある。 比較のために先に予測した值 $\sqrt{a r e a}_{\max }^{*}$ と一緒に Table III に示す. FCD70の $\sqrt{a r e a}_{0}$ は予測值とよく 一致している。，一方，FCD60 では予測值より若干小 さい結果になっている.これは FCD60の基地組織が フェライトとパーライトの面積率がほぼ等しい典型的 なブルスアイ組織であり，FCD70よりも局所的な強 度のばらつきが大きいことが主な原因と思われる。以 上の結果は, 間接的ではあるが, $\sqrt{\operatorname{area}}_{\text {max }}$ の寸法 程度の黒鉛が表面近傍に存在して疲労限度を決定して いることを示すものである. 
$\sqrt{a r e a}_{\text {max }}^{*}$ は, 球状黒鉛鋳鉄をはじめとして多孔 金属材料の度労強度を予測する際の幾何学的パラメー 夕となることが予想されるが, 一方, 疲労強度に影響 を及ぼさない介在物, ひっかき傷の寸法や表面仕上げ の粗さの限界値に関連して重要な尺度と考えられる.

具体的に式(1)によって $\sigma_{w}$ を予測するには, $\sqrt{a r e a}$ $\left(=\sqrt{a r e a}_{\max }^{*}\right)$ のほかに欠陷近傍の基地組織の硬さ $H_{v}$ が必要である. 硬さが場所によらず均一であれば欠陥 の影響が及ばない場所で $H_{v}$ を測定すればよい. しか し，球状黒鉛鋳鉄は，基地組織がブルスアイ組織のよ うに均一ではない場合があり，黒鉛どうしが接近して いるので, 硬さの測定法については今後検討が必要で ある。

\section{4 結言}

球状黒鉛鋳鉄 FCD60 と FCD70 相当材の回転曲げ 疲労試験を行い, 疲労強度に及ぼす表面黒鉛の影響と, 疲労限度を決定する欠陥の幾何学的パラメータについ て検討して，以下の結果を得た.

（1）本実験で使用した材料では，表面欠陥内に詰 まっている黒鉛そのものは疲労強度にほとんど関係し ていない.

（2）疲労限度は，投影面積の平方根によって定義さ れる表面直下の黒鉛の最大寸法 $\sqrt{a r e a}_{\max }^{*}$ によって 決まっていると推測される.

（3）極值統計を用いて予測した $\sqrt{a r e a}_{\text {max }}^{*}$ の值と 疲労限度を低下させない切欠きの限界深さに相当する $\sqrt{a r e a}$ の值は密接な関係にあった.

（4） $\sqrt{a r e a}_{\text {max }}^{*}$ は, 多孔金属材料の疲労強度を予 測する際に用いるべき欠陥の幾何学的パラメータであ る.

最後に, 黒鉛の面積と真円度の測定には, 九州工業 大学材料力学研究室の自動画像解析装置 PIAS LA500を使用させていただいた.ここに記して感謝 の意を表します.

（昭和63年11月10日 第19回疲労シンポジウムにて講演）

\section{参 考 文 献}

1 ) 大橋正昭, 黒田正義, 小松康彦, 日比野義博, 鋳物, 42, 634 (1970).

2) 新美 格, 大橋正昭, 小松康彦, 日比野義博, 鋳物, 43, 101 (1971).

3 ) 西谷弘信, 村上敬宜, 機械の研究, 25, 543 (1973).

4 ）祖父江昌久, 鋳物, 48, 441 (1976).
5 ) A. G. Fuller, AFS Trans., 85, 527 (1978).

6 ）塩田俊雄, 小松真一郎; 鋳物, 54, 434 (1982).

7 ) 祖父江昌久, 鋳物, 51，281（1979）.

8 ) 祖父江昌久, 鋳物, 51, 159 (1979).

9 ）祖父江昌久，鋳物， 53，635（1981）.

10）田中雄一, 河村公治, 加藤清夫, 井川克也, 鋳物, 53, 500 (1981).

11）鈴木秀人, 大薮 優, 植木忠司, 国尾 武, 日本機械学 会論文集, A-51, 1224 (1985).

12）鈴木秀人, 国尾 武, 日本機械学会論文集, A - 53, 1000 (1987).

13）村上敬宜, 遠藤正浩, 材料, 35, 911 (1986).

14) Y. Murakami and M. Endo, "The Behaviour of Short Fatigue Cracks", EGF Pub. 1 (Ed. by K. J. Miller and E. R. de los Rios), p. 275 (1986) Mech Engng Pub.

15）村上敬宜, 児玉昭太郎, 小沼静代, 日本機械学会論文集, A -54, 688 (1988).

16）村上敬宜, 宇宿尚史, 日本機械学会論文集, A-55, 213 (1989).

17）夏目喜孝, 宮川 進, 上村裕二朗, 村上敬宜, 第19回疲 労シンポジウム前刷集, p. 76 (1988).

18）江村秀樹, 浅見克敏, 日本機械学会論文集, A-55, 45 (1989).

19）西村 昭, 皆田 理, 材料, 37, 434 (1988).

20）矢野 满, 日本機械学会論文集, A-51, 132 (1985).

21）矢野 満, 日本機械学会論文集, A-52, 2150 (1986).

22）小川武史, 小林英男, 小出孝道, 中沢 - , 米谷英二, 日本機械学会論文集, A-51, 1660 (1985).

23）“鋳物便覧（改訂第 4 版）”, p. 567 (1986), 日本鋳物協 会.

24）并川克也, 田中雄一, 日本金属学会会報, 13, 665 (1974).

25）加藤容三, 中野典彦, 日本機械学会論文集, A - 50, 1565 (1984).

26）加藤容三, 中野典彦, 日本機械学会論文集, A - 51, 1208 (1985).

27）西谷弘信, 田中哲志, 日本機械学会論文集, A -51, 1442 (1985).

28) P. Clement, J. P. Angeli and A. Pineau, Fatigue Engng Mater. Struct., 7, 251 (1984).

29）広瀨幸雄, 黒部利次, 津田政明, 西本茂戸造, 河合茂治, 日本材料強度学会誌, 16, 156 (1981).

30）村上敬宜, 遠藤正浩; 日本機械学会論文集, A-49, 127 (1983).

31) E. J. Gumbel, “極值統計学”, 河田竜夫, 岩井重久, 加 瀬滋男監訳 (1978), 生産技術センター新社. 